\title{
Synthesis of Quaternary Amino Acids Bearing a (2'Z)- Fluorovinyl a-Branch: Potential PLP Enzyme Inactivators
}

\author{
David B. Berkowitz, Roberto de la Salud-Bea, and Wan-Jin Jahng \\ Department of Chemistry, University of Nebraska, Lincoln, Nebraska 68588-0304
}

\begin{abstract}
Protected $a$-formyl amino acids, themselves available from the corresponding $a$-vinyl amino acids, are stereoselectively transformed into the ( $Z$ )-configured $a$ - $\left(2^{\prime}\right.$-fluoro $)$ vinyl amino acids via a three-step sequence. The route employs McCarthy's reagent, diethyl a-fluoro-a(phenylsulfonyl)-methyl phosphonate, and proceeds via the intermediate ( $E$ )-a-fluorovinyl sulfones and (E)-a-fluorovinylstannanes. The latter may either be exploited as novel crosscoupling partners for fluorovinyl branch extension or be globally deprotected, to provide the title compounds.
\end{abstract}

\section{Graphical abstract}

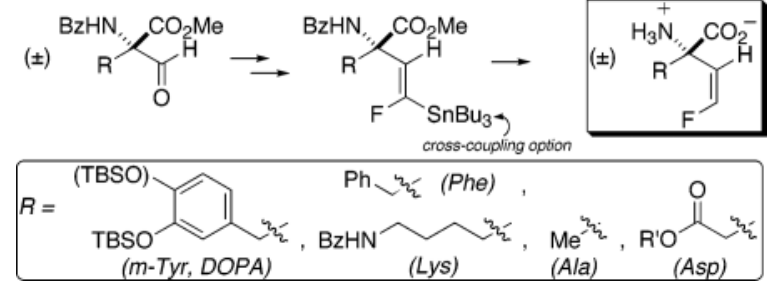

Quaternary, a-vinyl amino acids (AA's) are potential mechanism-based inactivators of pyridoxal phosphate (PLP) dependent enzymes, particularly amino acid decarboxylases (AADC's). ${ }^{1,2}$ The "vinylic trigger" is also found in the naturally occurring PLP-enzyme inactivator vinylglycine ${ }^{3}$ and in the anti-epileptic drug vigabatrin $(\gamma$-vinyl-GABA $),{ }^{4}$ which has gained attention more recently for its potential application in the treatment of substance abuse. ${ }^{5}$ Elegant work by Silverman and John has elucidated the mechanism by which the vinylic trigger in vigabatrin functions to inactivate GABA transaminase. ${ }^{6,7}$ Both electrophilic (Michael addition) and nucleophilic (Metzler-type enamine-PLP aldimine condensation $^{8}$ ) pathways are operative, each of which follows from the normal first two enzymatic steps (transaldimination $/ \boldsymbol{\gamma}$-proton abstraction).

Introduction of a $2^{\prime}$-fluorine atom into this trigger might lead to an alternative, potentially more electrophilic, ${ }^{9}$ Michael acceptor, on one hand, and might divert the Metzler enamine pathway into a second Michael addition pathway, on the other. Indeed, in the one case in

Correspondence to: David B. Berkowitz.

Supporting Information Available: Complete set of ${ }^{1} \mathrm{H}$ NMR and selected ${ }^{19} \mathrm{~F}$ NMR spectra, as well as experimental procedures and characterization data for all new compounds. This material is available free of charge via the Internet at http://pubs.acs.org. 
which such a trigger has been reported, for $\gamma$-( $2^{\prime}$-fluoro $)-\gamma$-vinyl-GABA inactivation of GABA transaminase, such changes in mechanism are evident, though multiple pathways are operative. ${ }^{10}$ Interestingly, in that case, the $(Z)$ - and $(E)$ - $\left(2^{\prime}\right.$-fluoro $)$ vinyl triggers give different profiles, highlighting the importance of accessing single geometric isomers. ${ }^{11}$

Given this, it would be interesting to install such a trigger at the a-carbon to probe its effectiveness in an AADC active site. Yet, to our knowledge, no syntheses of quaternary, a$\left(2^{\prime}\right.$-fluoro)vinyl AA's have yet been reported, though $(E)$ - and (Z)-a-( $2^{\prime}$-fluoro)vinylglycine have been described by McCarthy. ${ }^{12}$

A fluoromethylenation route related to McCarthy's ${ }^{13}$ was attractive, as protected $a$-formyl AA's might be obtained ozonolytically, from the corresponding quaternary, a-vinyl AA's. The latter were available, with appropriate protecting groups, via a formal a-vinylation sequence that had been developed earlier (Scheme 1). ${ }^{14}$ Furthermore, success in the racemic series here would map onto an enantioselective variant, starting from either L- or D-a-vinyl AA's. ${ }^{15}$ Pleasingly, the ozonolysis of vinylic AA's (4) to formyl AA's (5) proceeded in good to excellent yield, across an array of functionalized side chains (Table 1).

McCarthy had taken a Horner Wadsworth Emmons (HWE) approach, condensing lithio diethyl a-fluoro-a-(phenylsulfonyl)methylphosphonate (6) with the Garner aldehyde to obtain an $(E) /(Z)$ mixture of a-( $2^{\prime}$-fluoro)vinylglycinol isomers. ${ }^{12}$ In considering the application of this chemistry here, several key issues arose at the outset: (i) Would such sterically encumbered aldehydes (5) be amenable to nucleophilic attack by $\mathbf{6}$ ? (ii) If so, would the intermediate $\beta$-alkoxyphosphonates follow the desired HWE reaction mode or fragment along a competing "retro-Claisen" mode (Scheme 2)? (iii) Would any such HWE products be formed as an $E / Z$ mixture as is typical for this chemistry? ${ }^{12}$

Should these issues be addressable, this synthetic strategy would be redox-efficient in that the a-carboxyl group oxidation state would be preserved throughout. This route would also have the attractive feature of providing intermediate a-fluorovinylstannanes as potential vehicles for fluorovinyl branch extension. Indeed, as can be seen from Table 2, the targeted fluorovinyl sulfones were obtained in each case and as single geometric isomers. This level of diastereoselectivity is unusual for carbonyl condensation reactions of $\mathbf{6}$, and presumably is a reflection of the steric demand of the quaternary a-center. Furthermore, though the competing "retro-Claisen" manifold is observed, the HWE pathway predominates for all AA's but aspartate.

The subsequent tin-sulfone exchange proceeded smoothly under the agency of $\mathrm{Bu}_{3} \mathrm{SnH}$, generally in very high yield (Table 3). Surprisingly, only the (E)-stereoisomers were observed in the crude NMR spectra of these reactions. Previously, McCarthy had observed $E / Z$ equilibration in such transformations for fluorovinyl sulfones bearing a single $\beta$ substituent. ${ }^{12}$ Thus, the transformations $\mathbf{7 a - f} \rightarrow \mathbf{9 a}-\mathbf{f}$ may be the first examples of stereospecific tin-sulfonyl exchange for $\beta$-monosubstituted, a-fluorovinyl phenyl sulfones. ${ }^{16}$ Once again, attachment of a hindered quaternary center directly to the $\beta$-vinylic position appears to confer an unexpectedly high degree of stereocontrol. 
At this juncture, we selected stannane 9a as a model compound to examine its potential for chain extension to AA's bearing side chains with embedded fluorovinyl groups (Scheme 3). ${ }^{17}$ Stille-type couplings ${ }^{18}$ with aryl halides produced a-methylated and homologated analogues of phenylalanine (11) and $m$-tyrosine (13). A similar Pd-mediated coupling with ethyl chloroformate ${ }^{19}$ yielded the a-methylglutamate analogue $\mathbf{1 0}$.

Alternatively, tin-iodine exchange could be effected smoothly to 12, which could subsequently be engaged in a "ligandless" Suzuki coupling ${ }^{20}$ with $\mathrm{PhB}(\mathrm{OH})_{2}$, as an alternative route to $\mathbf{1 1}$ (Scheme 4). Pd-mediated Negishi-type coupling ${ }^{21}$ with $\mathrm{Me}_{2} \mathrm{Zn}$ or the analogous Ni-mediated procedure of Knochel ${ }^{22}$ could be applied to the synthesis of 14, an unusual analogue of a-methylleucine in which a fluorine atom takes the place of a methyl group.

Finally, upon refluxing in $6 \mathrm{~N} \mathrm{HCl}, \mathbf{7 a - f}$ could be protodestannylated with concomitant ester, ether, and amide hydrolysis to 15a-f, the free, quaternary, a-(2' $Z$-fluoro)-vinyl AA's, bearing side chains relevant to target PLP enzymes. Studies of this new class of potential AADC inactivators are now underway.

\section{Supplementary Material}

Refer to Web version on PubMed Central for supplementary material.

\section{Acknowledgments}

The authors thank the UNMC/Eppley Institute for Cancer Research for an LB-595 seed grant and the NIH (CA 62034) for support of preliminary studies. D.B.B. acknowledges the Alfred P. Sloan Foundation for a fellowship. This research was facilitated by shared instrumentation grants for NMR (NIH SIG-1-510-RR-06301, NSF CHE-0091975, NSF MRI-0079750) and GC/MS (NSF CHE-9300831), respectively.

\section{References}

1. Berkowitz DB, Jahng W-J, Pedersen ML. Bioorg. Med. Chem. Lett. 1996; 6:2151-2156. and references therein.

2. Note that the "quaternary" AA design, in and of itself, should provide some specificity, as classes of PLP enzymes that act by a-deprotonation should be incapable of actuating these triggers.

3. (a) ACC Synthase: Liang F, Kirsch JF. Biochemistry. 2000; 39:2436-2444. [PubMed: 10704193] (b) Cysteine desulfurase: Zheng L, White RH, Cash VL, Dean DR. Biochemistry. 1994; 33:4714-20. [PubMed: 8161529] (c) Kynurenine aminotransferase: Asada Y, Tanizawa K, Yonaha K, Soda K. Agric. Biol. Chem. 1988; 52:2873-2878.(d) Asp aminotransferase: Gehring H, Rando RR, Christen P. Biochemistry. 1977; 16:4832-4836. [PubMed: 911793] (e) D-AA transaminase: Soper TS, Manning JM, Marcotte PA, Walsh CT. J. Biol. Chem. 1977; 252:1571-1575. [PubMed: 402367]

4. Jung, MJ., Palfreyman, MG. Vigabatrin. In: Levy, RH., Mattson, RH., editors. Antiepileptic Drugs. 4. Raven; New York: 1995.

5. (a) Brodie JD, Figueroa E, Dewey SL. Synapse. 2003; 50:261-265. [PubMed: 14515344] (b) Gerasimov MR, Dewey SL. Drug Dev. Res. 2003; 59:240-248.

6. Mechanistic studies: Nanavati SM, Silverman RB. J. Am. Chem. Soc. 1991; 113:9341-9349.De Biase D, Barra D, Bossa F, Pucci P, John RA. J. Biol. Chem. 1991; 266:20056-20061. [PubMed: 1939068]

7. X-ray studies: Storici P, De Biase D, Bossa F, Bruno S, Mozzarelli A, Peneff C, Silverman RB, Schirmer T. J. Biol. Chem. 2004; 279:363-373. [PubMed: 14534310]

8. Ueno H, Likos JJ, Metzler DE. Biochemistry. 1982; 21:4387-4393. [PubMed: 6812625] 
9. Zhou H, Schmidt DMZ, Gerlt JA, van der Donk WA. Chem BioChem. 2003; 4:1206-1215.

10. Silverman RB, Bichler KA, Leon AJ. J. Am. Chem. Soc. 1996; 118:1253-1261.

11. For a related trigger bearing both $E$ - and $Z$-configured fluorines, see: Pan Y, Qiu J, Silverman RB. J. Med. Chem. 2003; 46:5292-5293. [PubMed: 14640537]

12. McCarthy JR, Huber EW, Le T-B, Laskovics FM, Matthews DP. Tetrahedron. 1996; 52:45-58.

13. For other examples of HWE-type condensations with 6, see: McCarthy JR, Matthews DP, Paolini JP. Org. Synth. 1995; 72:216-24.Gross RS, Mehdi S, McCarthy JR. Tetrahedron Lett. 1993; 34:7197-7200.McCarthy JR, Matthews DP, Stemerick DM, Huber EW, Bey P, Lippert BJ, Snyder RD, Sunkara PS. J. Am. Chem. Soc. 1991; 113:7439-7440.

14. Pedersen ML, Berkowitz DB. J. Org. Chem. 1993; 58:6966-6975.Pedersen ML, Berkowitz DB. Tetrahedron Lett. 1992; 33:7315-7318.See also: Columbo L, Di Giacomo M, Vinci V, Columbo M, Manzoni L, Scolastico C. Tetrahedron. 2003; 59:4501-4513.

15. For enantioselective syntheses of quaternary, a-vinyl AA's, see: Ma D, Zhu W. J. Org. Chem. 2001; 66:348-350. [PubMed: 11429926] Berkowitz DB, McFadden JM, Chisowa E, Semerad CL. J. Am. Chem. Soc. 2000; 122:11031-11032.Berkowitz DB, McFadden JM, Sloss MK. J. Org. Chem. 2000; 65:2907-2918. [PubMed: 10814177] Avenoza A, Cativiela C, Corzana F, Peregrina JM, Zurbano MM. J. Org. Chem. 1999; 64:8220-8225. [PubMed: 11674740] Berkowitz DB, Pumphrey JA, Shen Q. Tetrahedron Lett. 1994; 35:8743-8747.Colson P-J, Hegedus LS. J. Org. Chem. 1993; 58:5918-5924.Seebach D, Bürger HM, Schickli CP. Liebigs Ann. Chim. 1991:669684.Weber T, Aeschimann R, Maetzke T, Seebach D. Helv. Chim. Acta. 1986; 69:13651377.Groth U, Schöllkopf U, Chiang Y-C. Synthesis. 1982:864-866.

16. In support of this, McCarthy does observe a stereospecific conversion of $\beta$, $\beta$-disubstituted fluorovinyl phenyl sulfones to the corresponding stannanes (ref 11). However, in the absence of data for the stannylation of the $(Z$ )-isomers of $\mathbf{7}$, one cannot rigorously rule out an equilibration mechanism here. In this context, it is well to note that vinyl stannanes are known to isomerize upon heating in the presence of tin hydrides: Leusink AJ, Budding HA. J. Organomet. Chem. $1968 ; 11: 541-547$.

17. For a related cross-coupling approach to a-branch extension for nonfluorinated quaternary AA's, see: Berkowitz DB, Chisowa E, McFadden JM. Tetrahedron. 2001; 57:6329-6343.

18. (a) Sheffy FK, Godschalx JP, Stille JK. J. Am. Chem. Soc. 1984; 106:4833-4840.(b) Chen C, Wilcoxen K, Zhu Y-F, Kim K, McCarthy JR. J. Org. Chem. 1999; 64:3476-3482. [PubMed: 11674468]

19. (a) Soderquist JA, Rosado I, Marrero I, Burgos C. ARKIVOC. 2001; 4:12-19.(b) Jeong IH, Park YS, Kim MS, Song YS. J. Fluorine Chem. 2003; 120:195-209.

20. For other examples and a discussion of "ligandless" Suzuki conditions, see: Goodson FE, Wallow TI, Novak BM. Org. Synth. 1998; 75:61-68.See also: Chen C, Wilcoxen K, Strack N, McCarthy JR. Tetrahedron Lett. 1999; 40:827-830.

21. Negishi, E-I. Organozinc Reagents. Knochel, P., Jones, P., editors. Oxford University; Oxford, UK: 1999. p. 213-243.

22. Giovannini R, Stüdemann T, Dussin G, Knochel P. Angew. Chem., Int. Ed. Engl. 1998; 37:23872390.

Org Lett. Author manuscript; available in PMC 2017 August 30. 
<smiles>[R]C(NC(=O)c1ccccc1)C(=O)OC</smiles>

1

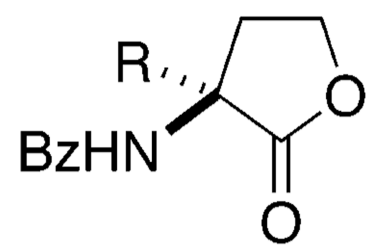

( \pm ) 3

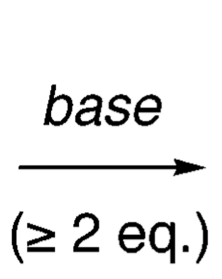

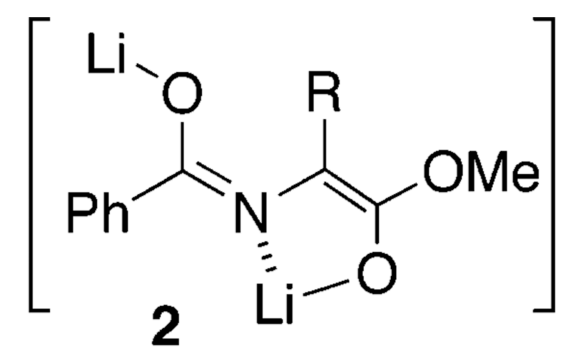

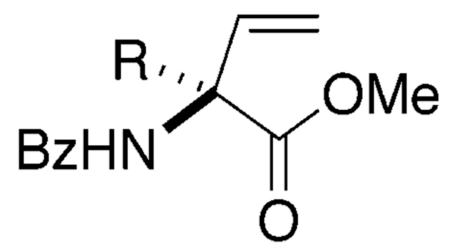

(土) 4

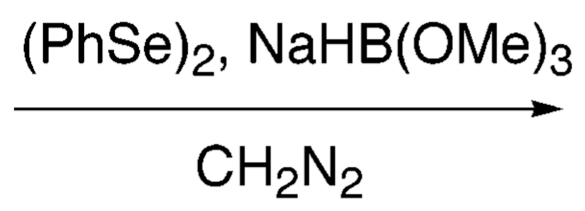

Scheme 1.

Formal a-Vinylation of Amino Acids 


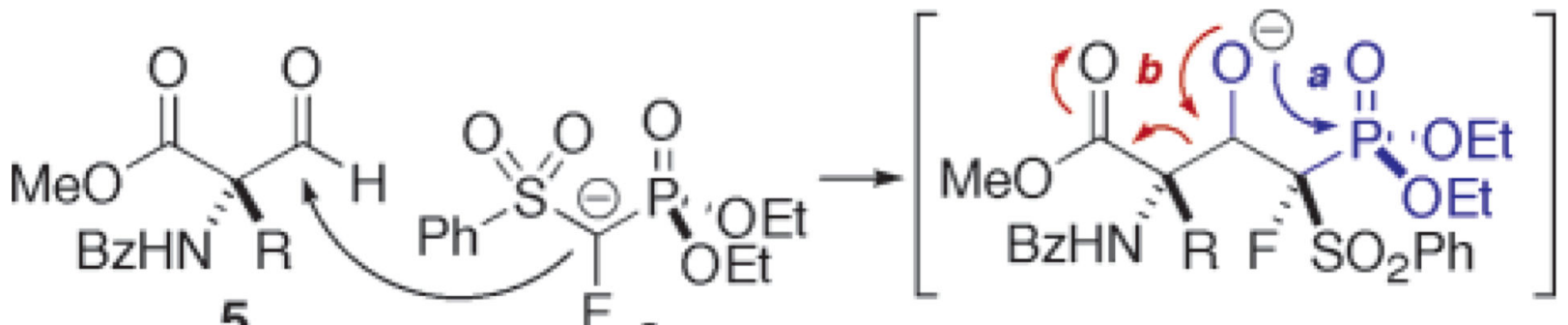

5

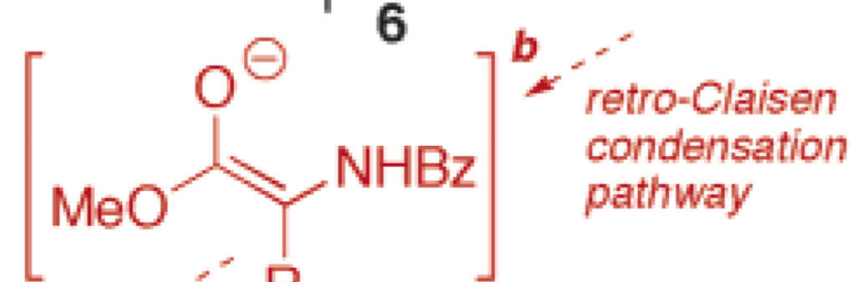

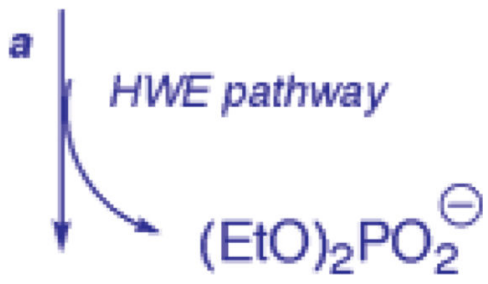<smiles>[R18]NC(C)C(=O)OC</smiles>

$8 \mathrm{R} \begin{aligned} & \text { deformylation } \\ & \text { byproduct }\end{aligned}$<smiles>[R]C(N=Cc1ccccc1)C(=O)O[Na]</smiles>

Scheme 2.

Competition between HWE and "Retro-Claisen" Condensation Manifolds 
(homo-Phe analogue)

( \pm ) 11<smiles>CCCC(C)(NC(=O)c1ccccc1)C(=O)OC</smiles>

(Glu analogue)<smiles>CCOC(=O)/C(F)=C(\CC)[C@](C)(NC(=O)c1ccccc1)C(C)=O</smiles>

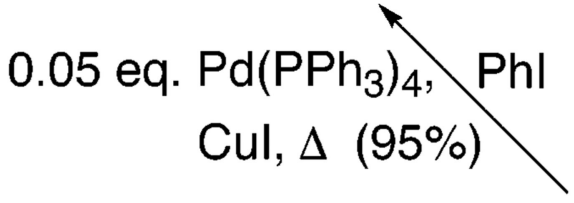

0.1 eq. $\mathrm{Cl}_{2} \mathrm{Pd}\left(\mathrm{PPh}_{3}\right)_{2}$, $\mathrm{ClCO}_{2} \mathrm{Et}, \mathrm{CuCN}$, $/ \mathrm{PhMe}, \Delta(68 \%)$
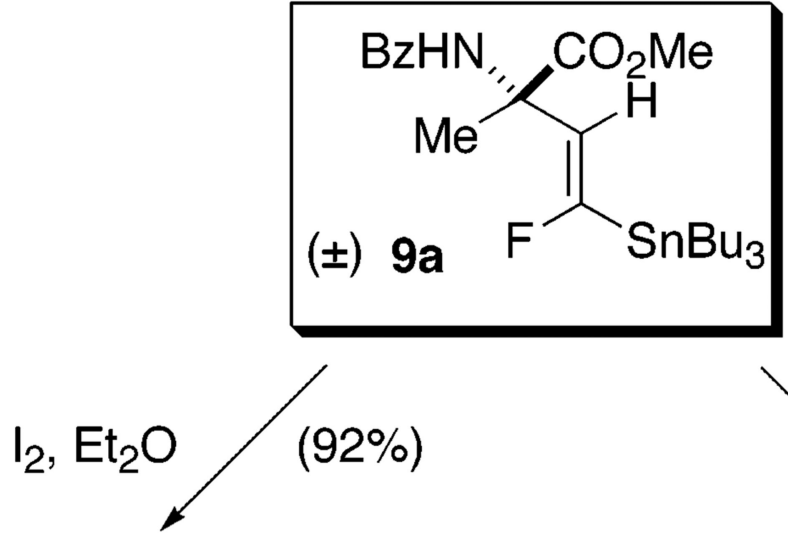

$m-\mathrm{TBSO}-\mathrm{C}_{6} \mathrm{H}_{4}-\mathrm{I}$,
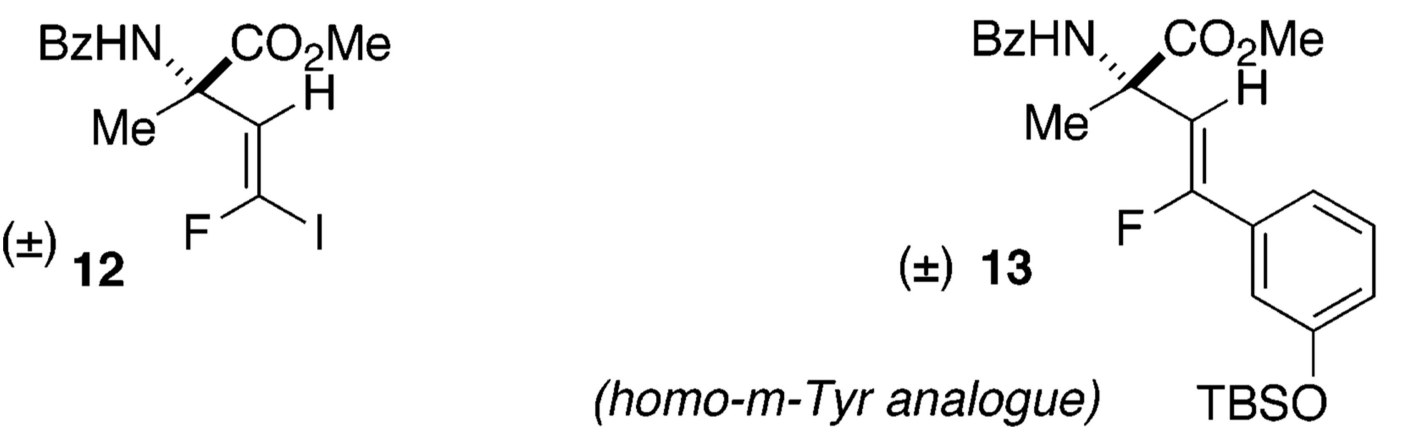

Scheme 3.

Introduction of Fluoroalkene-Embedded Side Chain Functionality via Stille-Type Coupling 


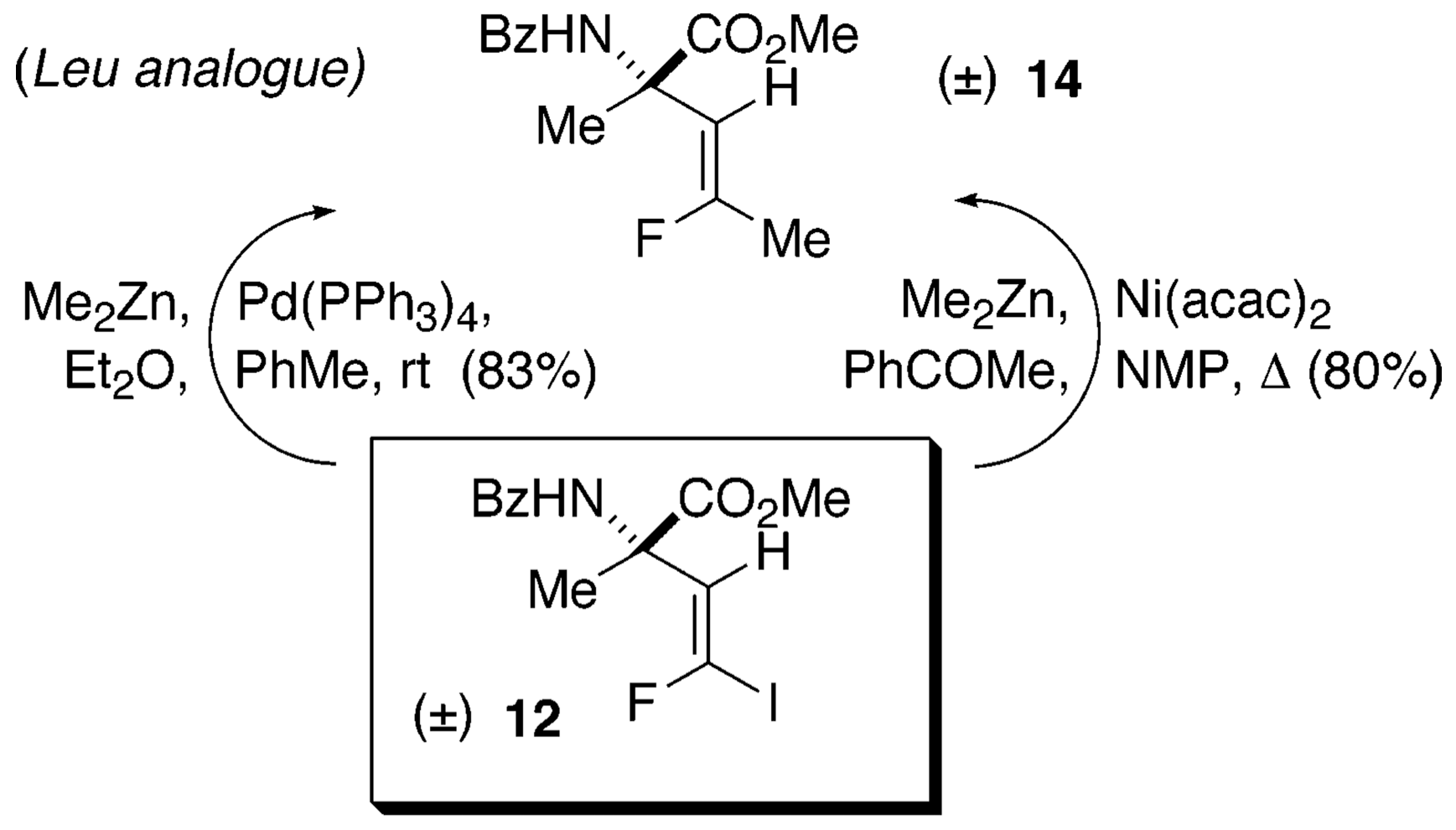

$\mathrm{PhB}(\mathrm{OH})_{2}, \quad \mathrm{Pd}_{2}(\mathrm{dba})_{3}$,

$\mathrm{KOH}, \mathrm{THF}, \mathrm{H}_{2} \mathrm{O}$, rt (95\%)

$\mathrm{BzHN}, \mathrm{CO}_{2} \mathrm{Me}$

(homo-Phe analogue)

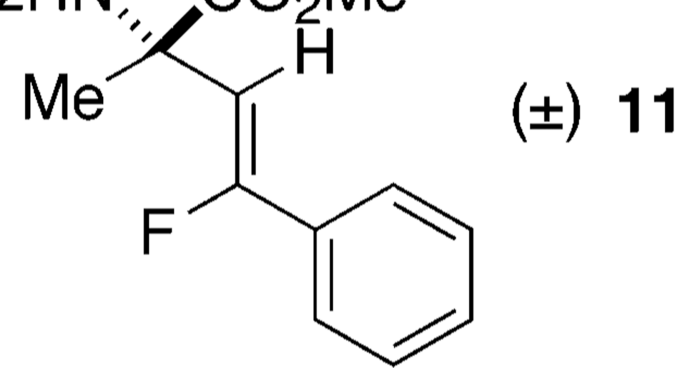

Scheme 4.

Negishi and Suzuki-Type Couplings on a-Fluorovinyl Iodide 12 


\section{Table 1}

From Vinyl AA's to Formyl AA's ${ }^{a}$

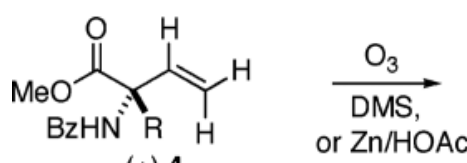

(土) 4

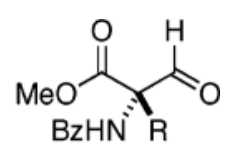

( \pm ) 5

\begin{tabular}{|c|c|c|c|c|}
\hline entry & $\mathbf{R}$ & $\mathbf{A A}$ & $\begin{array}{l}\text { reduction } \\
\operatorname{method}^{b}\end{array}$ & $\begin{array}{l}\text { yield } \\
\text { of } 5^{c}\end{array}$ \\
\hline $\mathbf{a}$ & $\mathrm{Me}$ & Ala & A1 & $87 \%$ \\
\hline b & & Phe & A2 & $93 \%$ \\
\hline c & & $m$-Tyr & A2 & $66 \%$ \\
\hline d & & DOPA & A2 & $99 \%$ \\
\hline $\mathbf{e}$ & & Lys & A2 & $84 \%$ \\
\hline f & & Asp & A1 & $65 \%$ \\
\hline
\end{tabular}

${ }^{a}$ Procedure: Ozone was bubbled into a solution of the protected vinyl-AA $(\mathbf{4 a - f})$ in $\mathrm{CH}_{2} \mathrm{Cl}_{2}$ at $-78{ }^{\circ} \mathrm{C}$, until a light blue color persisted. After several minutes, oxygen was then bubbled through to remove excess ozone (decolorizes).

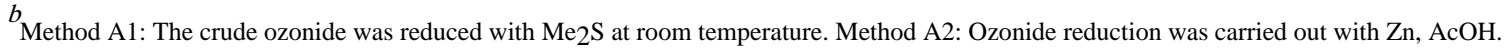

$c_{\text {Isolated yields. }}$ 


\section{Table 2}

A Stereoselective McCarthy-Type HWE Reaction ${ }^{a}$

\begin{tabular}{|c|c|c|c|c|}
\hline entry & $\mathbf{R}$ & $\mathbf{A A}$ & $\begin{array}{l}\text { yield } \\
\text { of } 7^{b}\end{array}$ & $\begin{array}{c}\text { yield of } \\
8^{c}\end{array}$ \\
\hline $\mathbf{a}$ & $\mathrm{Me}$ & Ala & $74 \%$ & trace \\
\hline b & & Phe & $44 \%$ & nd \\
\hline c & & $m$-Tyr & $55 \%$ & $5 \%$ \\
\hline d & & DOPA & $57 \%$ & $17 \%$ \\
\hline e & & Lys & $61 \%$ & $24 \%$ \\
\hline $\mathbf{f}$ & & Asp & $41 \%$ & $41 \%$ \\
\hline
\end{tabular}

a Procedure: To a solution of McCarthy's reagent (1.2. equiv) in THF at $-78^{\circ} \mathrm{C}$ was added LiHMDS (1.4 equiv, $1 \mathrm{M}$ in hexanes) and stirring was continued for $20 \mathrm{~min}$. Then, a solution of a-formyl AA (5) in THF at $-78{ }^{\circ} \mathrm{C}$ was added via cannula. The reaction was allowed to warm to room temperature, and quenched with $\mathrm{NH}_{4} \mathrm{Cl}$ (aq) once $\mathbf{5}$ had been consumed and a predominant spot for $\mathbf{7}$ was visible on TLC.

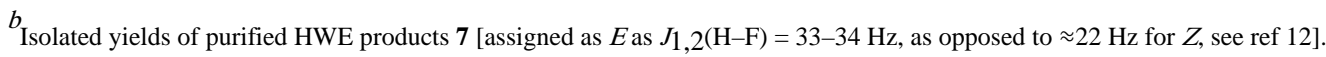

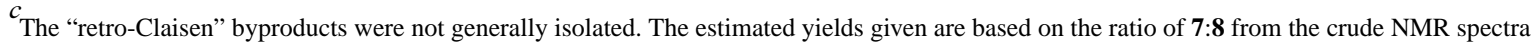
and the isolated yields of 7 .

Org Lett. Author manuscript; available in PMC 2017 August 30. 
Table 3

Sulfone/Stannane Interchange with Retention of Configuration ${ }^{a}$

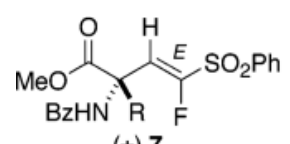

(士) 7

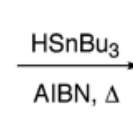

AIBN, $\Delta$

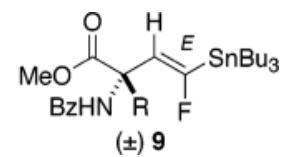

(士) 9

\begin{tabular}{cllc}
\hline entry & $\mathbf{R}$ & $\mathbf{A A}$ & $\begin{array}{c}\text { yield of } \\
\mathbf{9}, \boldsymbol{b} \text { \% }\end{array}$ \\
\hline a & $\mathrm{Me}$ & $\mathrm{Ala}$ & 80 \\
$\mathbf{b}$ & $\mathrm{CH}_{2} \mathrm{Ph}$ & $\mathrm{Phe}$ & 91 \\
c & $\mathrm{CH}_{2}\left(3^{\prime}-\mathrm{OTBS}\right) \mathrm{C}_{6} \mathrm{H}_{4}$ & $m$-Tyr & 97 \\
d & $\mathrm{CH}_{2}\left(3^{\prime}, 4^{\prime}\right.$-bis-OTBS $) \mathrm{C}_{6} \mathrm{H}_{3}$ & DOPA & 79 \\
e & $\left(\mathrm{CH}_{2}\right)_{4} \mathrm{NHBz}$ & Lys & 76 \\
f & $\mathrm{CH}_{2} \mathrm{CO}_{2} \mathrm{Me}$ & Asp & 50 \\
\hline
\end{tabular}

${ }^{a}$ Procedure: An Ar-purged solution of $\mathbf{7}$ in benzene containing AIBN (glovebag) and Bu3 SnH (1 equiv) was heated at reflux, until complete conversion to 9 was evident by TLC.

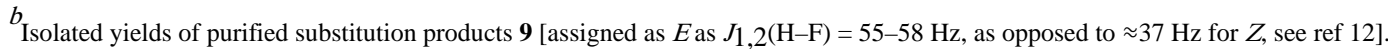




\section{Table 4}

Global Deprotection to the Target a-(2' $Z$-Fluoro)vinyl-AA's ${ }^{a}$

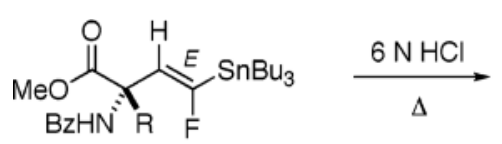

(士) 9

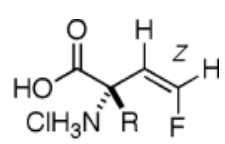

(士) 15

\begin{tabular}{|c|c|c|c|}
\hline entry & $\mathbf{R}^{b}$ & $\mathbf{A A}$ & yield \\
\hline $\mathbf{a}$ & $\mathrm{Me}$ & Ala & $89 \% d$ \\
\hline b & & Phe & $85 \%$ \\
\hline c & & m-Tyr & $88 \% d$ \\
\hline d & & DOPA & $93 \% d$ \\
\hline e & & Lys & $63 \%{ }^{e}$ \\
\hline $\mathbf{f}$ & & Asp & $52 \%{ }^{e}$ \\
\hline
\end{tabular}

a Procedure: The fully protected stannylvinyl amino acid (9) was suspended in $6 \mathrm{~N} \mathrm{HCl}$ and refluxed for $12-30 \mathrm{~h}$.

$b_{\mathrm{R}}$ debenzoylated, and those of $m$-Tyr and DOPA are desilylated. Geometry is assigned as $Z$ as $J_{1}, 2(\mathrm{H}-\mathrm{F})=43-46 \mathrm{~Hz}$, as opposed to $\approx 17 \mathrm{~Hz}$ for $E$, see ref 10$]$.

$d$ These fluorovinyl AA's were isolated as their hydrochloride salts.

$e^{e}$ Further purified by Dowex 50 cation exchange chromatography. 